\title{
Muslim Population in Europe: 1950 - 2020
}

\author{
Houssain Kettani
}

\begin{abstract}
The purpose of this manuscript is to present a reliable estimate of the Muslim population and its percentage in each country in Europe from 1950 till 2020. This data is summarized to be a reference for other studies and discussions related to the Muslim population. The presented data show that the percentage of World Muslim population with respect to the total World population has increased steadily from $17 \%$ in 1950 to $26 \%$ by 2020 . While the total European population increased from 548 million in 1950 to 744 million by 2020, the percentage of Muslims in Europe increased from $2 \%$ in 1950 to $6 \%$ by 2020 .
\end{abstract}

\section{INTRODUCTION AND METHODOLOGY}

Europe was the third continent; after Asia and Africa, to which Islam has entered. Although Islam has a deep history in Europe, the results of this paper reveal that the percentage of Muslims in Europe is very low. The total population of Europe increased from 548 million in 1950 to 744 million by 2020 . The related Muslim population increased from $2 \%$ in 1950 to $6 \%$ by 2020 .

Our results are summarized in tables and a superscript number is put by a country name representing the source of the percentages. A "(year)" sign is put next to this number to indicate that the source bases its estimate on official census data and the year the census was conducted. Percentage values are based on the latest available census and reliable estimates. Official censuses were considered in this study to be the most reliable; although official censuses are usually challenged by minorities, whether Muslims or not, claiming that their number is underestimated for various reasons. However, these claims tend to be based on emotions and wishful thinking and not on scientific facts. In addition, residents who are not citizens are not counted in many religious and ethnic censuses. While typically non-citizens do not influence the political life in a country, they do help in establishing and maintaining various religious facilities and activities. Thus, it makes sense to include them in an estimate that inquires about adherents of a certain religion in a country.

However, not all censuses inquire on religious adherence, nor are held regularly. Thus, our second source of estimates is Demographic and Health Surveys (DHS) that include data on religion. When no census or Survey is available, we resort to other estimates from reliable sources. The total population estimate for each country and the corresponding annual population growth rate (APGR) since 1950 are based on [UNP]. An estimate for the Muslims demographics in the decennial estimates based on these growth rates.

H. Kettani is with the Department of Electrical and Computer Engineering and Computer Science, Polytechnic University of Puerto Rico, San Juan, Puerto Rico, USA. E-Mail: hkettani@pupr.edu
We divided Europe into six regions; the data for each is included in a separate section, and are sorted in terms of the percentage of Muslims in descending order. These regions are the Balkan Peninsula (Section 2), Eastern Europe (Section 3), Northwestern Europe (Section 4), the Nordic region (Section 5), Central Europe (Section 6), and Southwestern Europe (Section 7). Section 8 presents a summary of the data for the whole continent.

\section{MUSLIMS IN THE BALKAN PENINSULA}

This region consists of eleven countries: Albania, Bosnia and Herzegovina, Bulgaria, Croatia, Greece, Kosovo, Macedonia, Montenegro, Romania, Serbia, and Slovenia. The total population of this region increased from 16 million in 1870 , to 49 million in 1950 , to 65 million by 2020 . The related Muslim population changed from $15 \%$ in 1870 , to $8 \%$ in 1950 , to $14 \%$ by 2020 . The corresponding individual data for each country in this region is discussed below and summarized in Table 2. For the former Yugoslav republics, the 1991 census and the ones afterwards included religious data. However, previous censuses included ethnic data from which we can deduce religious affiliation. In our estimate, only the following ethnic groups were considered Muslim: Albanian, Muslim, Roma (Gypsy) and Turk. We also included Yugoslav ethnic declaration for the 1948-1961 censuses as Muslims were not given the option to declare that they are Muslim by ethnicity or Bosniacs.

2.1. Albania: Based on census data, the Muslim population increased from 688,000 or $68.59 \%$ in 1930 , to 779,417 or $69.09 \%$ in 1942 , to 860,000 or $68.80 \%$ in 1953 , to $1,580,000$ or $71.17 \%$ in 1971 , to $2,110,000$ or $75 \%$ in 1982. According to a 2009 DHS, this percentage increased to $79.59 \%$.

2.2. Bosnia and Herzegovina: Based on census data, the Muslim population changed from 448,613 or $38.73 \%$ in 1879 , to 492,710 or $36.88 \%$ in 1885 , to 548,632 or $34.99 \%$ in 1895 , to 612,137 or $32.25 \%$ in 1910 , to 588,247 or $31.13 \%$ in 1921 , to 717,000 or $31.31 \%$ in 1931 , to 890,094 or $33.37 \%$ in 1948 , to 913,669 or $32.08 \%$ in 1953 , to $1,124,173$ or $34.30 \%$ in 1961 , to $1,488,127$ or $39.72 \%$ in 1971 , to $1,641,957$ or $39.81 \%$ in 1981 , to $1,917,012$ or $43.80 \%$ in 1991.

2.3. Bulgaria: Based on census data, the Muslim population changed from 578,060 or $28.79 \%$ in 1881 , to 676,215 or $21.44 \%$ in 1888 , to 643,300 or $17.18 \%$ in 1900 , to 603,867 or $14.96 \%$ in 1905 , to 602,078 or $13.88 \%$ in 1910 , to 690,734 or $14.25 \%$ in 1920 , to 789,296 or $14.41 \%$ in 1926 , to 821,298 or $13.51 \%$ in 1934 , to 938,418 or $13.35 \%$ in 1946 , to $1,075,000$ or $14.14 \%$ in 1956 , to $1,450,000$ or $17.01 \%$ in 1971 , to $1,700,000$ or $19.3 \%$ in 1982 , to $1,112,331$ or $13.11 \%$ in 1992 , to 966,978 or $12.20 \%$ in 2001 . 
2.4. Croatia: Based on census data, the total Croatian population changed from $3,779,858$ in 1948 , to $4,159,696$ in 1961 , to $4,426,221$ in 1971 , to $4,601,469$ in 1981 , to $4,784,265$ in 1991 to $4,437,460$ in 2001 . The corresponding
Muslim population increased from 2,130 or $0.06 \%$ in 1948 , to 23,822 or $0.57 \%$ in 1961 , to 24,110 or $0.55 \%$ in 1971 , to 33,883 or $0.74 \%$ in 1981 , to 54,814 or $1.15 \%$ in 1991 , to 56,777 or $1.28 \%$ in 2001 .

\begin{tabular}{|c|c|c|c|c|c|c|c|c|c|}
\hline & & 1950 & 1960 & 1970 & 1980 & 1990 & 2000 & 2010 & 2020 \\
\hline \multirow{5}{*}{ 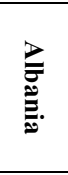 } & Population & $1,215,002$ & $1,610,565$ & $2,135,599$ & $2,671,300$ & $3,289,483$ & $3,067,556$ & $3,169,087$ & $3,273,979$ \\
\hline & Muslims \% & 68.80 & 68.80 & \begin{tabular}{|l|l|}
71.17 \\
\end{tabular} & \begin{tabular}{|l|l|}
71.17 \\
\end{tabular} & 79.59 & 79.59 & 79.59 & 79.59 \\
\hline & Muslims & 835,921 & $1,108,069$ & $1,519,906$ & $1,901,164$ & $2,618,100$ & $2,441,468$ & $2,522,276$ & $2,605,759$ \\
\hline & APGR \% & & 2.858 & 2.862 & 2.263 & 2.103 & -0.696 & 0.326 & \\
\hline & Reference & {$[$ KET] $(1953)$} & & {$[$ KET] $(1971)$} & & & & {$[\mathrm{AL}](2009 \mathrm{~s})$} & \\
\hline \multirow{5}{*}{ 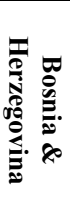 } & Population & $2,661,293$ & $3,180,020$ & $3,396,402$ & $3,747,109$ & $4,121,595$ & $3,332,123$ & $3,781,274$ & $4,290,968$ \\
\hline & Muslims \% & 33.37 & 34.30 & 39.72 & 39.81 & 43.80 & 43.80 & 43.80 & 43.80 \\
\hline & Muslims & 888,073 & $1,090,747$ & $1,349,051$ & $1,491,724$ & $1,805,259$ & $1,459,470$ & $1,656,198$ & $1,879,444$ \\
\hline & APGR \% & & 1.797 & 0.660 & 0.988 & 0.957 & -2.104 & 1.273 & \\
\hline & Reference & {$[\mathrm{BAH}](1948 \mathrm{e})$} & {$[\mathrm{BA}](1961 \mathrm{e})$} & {$[\mathrm{BA}](1971 \mathrm{e})$} & {$[\mathrm{BA}](1981 \mathrm{e})$} & {$[\mathrm{BA}](1991 \mathrm{e})$} & & & \\
\hline \multirow{5}{*}{ 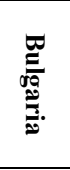 } & Population & $7,250,999$ & $7,867,008$ & $8,489,572$ & $8,861,536$ & $8,818,915$ & $8,006,072$ & $7,497,282$ & $7,020,826$ \\
\hline & Muslims \% & 13.35 & 14.14 & 17.01 & 19.30 & 13.11 & 12.20 & 12.20 & 12.20 \\
\hline & Muslims & 968,008 & $1,112,395$ & $1,444,076$ & $1,710,276$ & $1,156,160$ & 976,741 & 914,668 & 856,541 \\
\hline & APGR \% & & 0.819 & 0.765 & 0.430 & -0.048 & -0.962 & -0.654 & \\
\hline & Reference & [UN56](1946) & {$[$ KET](1956) } & {$[$ KET](1971) } & {$[\mathrm{KET}]$} & {$[\mathrm{BG}](1992)$} & {$[\mathrm{UN}](2001)$} & & \\
\hline \multirow{5}{*}{ 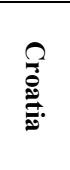 } & Population & $3,850,295$ & $4,045,251$ & $4,169,215$ & $4,376,609$ & $4,517,199$ & $4,505,422$ & $4,409,659$ & $4,315,931$ \\
\hline & \begin{tabular}{|l|} 
Muslims \% \\
\end{tabular} & 0.06 & 0.57 & 0.55 & 0.74 & 1.15 & 1.28 & 1.28 & 1.28 \\
\hline & \begin{tabular}{|l|} 
Muslims \\
\end{tabular} & 2,310 & 23,058 & 22,931 & 32,387 & 51,948 & 57,669 & 56,444 & 55,244 \\
\hline & APGR \% & & 0.495 & 0.302 & 0.487 & 0.317 & -0.026 & -0.215 & \\
\hline & \begin{tabular}{|l|} 
Reference \\
\end{tabular} & {$[\mathrm{HR}](1948)$} & {$[\mathrm{HR}](1961)$} & {$[\mathrm{HR}](1971)$} & {$[\mathrm{HR}](1981)$} & [UN](1991) & {$[\mathrm{UN}](2001)$} & & \\
\hline \multirow{5}{*}{$\begin{array}{l}2 \\
\overparen{8} \\
\overparen{8} \\
\overparen{8}\end{array}$} & Population & $7,566,002$ & $8,333,499$ & $8,793,002$ & $9,642,504$ & $10,160,501$ & $10,942,311$ & $11,183,393$ & $11,429,787$ \\
\hline & \begin{tabular}{|l|} 
Muslims \% \\
\end{tabular} & 1.48 & 1.37 & 1.25 & 1.66 & \begin{tabular}{|l|}
1.66 \\
\end{tabular} & \begin{tabular}{|l|}
0.90 \\
\end{tabular} & 2.86 & 2.86 \\
\hline & \begin{tabular}{|l|} 
Muslims \\
\end{tabular} & 111,977 & 114,169 & 109,913 & 160,066 & 168,664 & 98,481 & 319,845 & 326,892 \\
\hline & APGR \% & & 0.971 & 0.538 & 0.927 & 0.525 & 0.744 & 0.218 & \\
\hline & Reference & [UN56](1951) & [KET](1961) & [KET](1971) & {$[\mathrm{KET}]$} & & [DOS01] & {$[\mathrm{DOS}]$} & \\
\hline \multirow{5}{*}{$\begin{array}{l}\bar{R} \\
\delta \\
\varrho \\
0\end{array}$} & Population & 733,034 & 963,988 & $1,243,093$ & $1,584,440$ & $1,956,196$ & $2,000,000$ & $2,180,686$ & $2,377,696$ \\
\hline & Muslims \% & 69.68 & 70.08 & 75.82 & 80.37 & 84.46 & 93.52 & 93.52 & 93.52 \\
\hline & \begin{tabular}{|l|} 
Muslims \\
\end{tabular} & 510,778 & 675,563 & 942,513 & $1,273,414$ & $1,652,203$ & $1,870,400$ & $2,039,378$ & $2,223,621$ \\
\hline & APGR \% & & 2.777 & 2.575 & 2.456 & 2.130 & 0.222 & 0.869 & \\
\hline & Reference & {$[\mathrm{KO}](1948 \mathrm{e})$} & {$[\mathrm{KO}](1961 \mathrm{e})$} & {$[\mathrm{KO}](1971 \mathrm{e})$} & {$[\mathrm{KO}](1981 \mathrm{e})$} & {$[\mathrm{KO}](1991 \mathrm{e})$} & & {$[\mathrm{KO}](2006 \mathrm{e})$} & \\
\hline \multirow{5}{*}{ 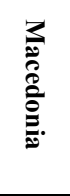 } & Population & $1,229,699$ & $1,392,001$ & $1,567,968$ & $1,794,830$ & $1,909,349$ & $2,011,614$ & $2,043,360$ & $2,075,607$ \\
\hline & Muslims \% & 27.29 & 24.05 & 25.14 & 28.62 & 30.06 & 33.33 & 33.33 & 33.33 \\
\hline & \begin{tabular}{|l|} 
Muslims \\
\end{tabular} & 335,585 & 334,776 & 394,187 & 513,680 & 573,950 & 670,471 & 681,052 & 691,800 \\
\hline & APGR \% & & 1.247 & 1.197 & 1.360 & 0.620 & 0.523 & 0.157 & \\
\hline & Reference & {$[\mathrm{MK}](1948 \mathrm{e})$} & {$[\mathrm{MK}](1961 \mathrm{e})$} & {$[\mathrm{MK}](1971 \mathrm{e})$} & {$[\mathrm{MK}](1981 \mathrm{e})$} & {$[\mathrm{UN}](1991)$} & {$[\mathrm{UN}](2002)$} & & \\
\hline \multirow{5}{*}{ 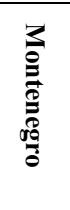 } & Population & 398,539 & 466,674 & 518,727 & 576,068 & 586,954 & 660,628 & 625,516 & 592,270 \\
\hline & Muslims \% & 5.79 & 12.80 & 20.14 & 20.07 & 21.25 & 17.74 & 17.74 & 17.74 \\
\hline & Muslims & 23,075 & 59,734 & 104,472 & 115,617 & 124,728 & 117,195 & 110,967 & 105,069 \\
\hline & APGR \% & & 1.591 & 1.063 & 1.054 & 0.187 & 1.189 & -0.545 & \\
\hline & Reference & {$[Y U](1948 \mathrm{e})$} & {$[Y U](1961 \mathrm{e})$} & {$[Y U](1971 \mathrm{e})$} & {$[\mathrm{ME}](1981 \mathrm{e})$} & {$[\mathrm{ME}](1991 \mathrm{e})$} & {$[\mathrm{ME}](2003)$} & & \\
\hline \multirow{5}{*}{ 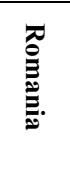 } & Population & $16,310,998$ & $18,407,000$ & $20,252,541$ & $22,201,389$ & $23,206,717$ & $22,137,869$ & $21,190,154$ & $20,283,010$ \\
\hline & Muslims \% & 0.18 & 0.20 & 0.21 & 0.22 & 0.25 & 0.31 & 0.31 & 0.31 \\
\hline & \begin{tabular}{|l|} 
Muslims \\
\end{tabular} & 29,360 & 36,814 & 42,530 & 48,843 & 58,017 & 68,627 & 65,689 & 62,877 \\
\hline & APGR \% & & 1.216 & 0.960 & 0.923 & 0.444 & -0.470 & -0.437 & \\
\hline & Reference & {$[\mathrm{RO}](1948 \mathrm{e})$} & {$[\mathrm{RO}](1956 \mathrm{e})$} & {$[\mathrm{RO}](1966 \mathrm{e})$} & {$[\mathrm{RO}](1977 \mathrm{e})$} & {$[\mathrm{UN}](1992)$} & {$[\mathrm{UN}](2002)$} & & \\
\hline \multirow{5}{*}{$\begin{array}{l}\mathscr{2} \\
\stackrel{2}{\vdots} \\
\frac{\mathfrak{d}}{2}\end{array}$} & Population & $5,999,221$ & $6,619,336$ & $6,929,553$ & $7,361,636$ & $7,612,549$ & $8,134,031$ & $7,675,171$ & $7,242,196$ \\
\hline & Muslims \% & 1.59 & 2.60 & 3.67 & 4.76 & 4.33 & 3.20 & 3.20 & 3.20 \\
\hline & \begin{tabular}{|l|} 
Muslims \\
\end{tabular} & 95,388 & 172,103 & 254,315 & 350,414 & 329,623 & 260,289 & 245,605 & 231,750 \\
\hline & APGR \% & & 0.989 & 0.459 & 0.607 & 0.336 & 0.665 & -0.579 & \\
\hline & Reference & {$[\mathrm{YU}](1948 \mathrm{e})$} & {$[\mathrm{YU}](1961 \mathrm{e})$} & {$[\mathrm{YU}](1971 \mathrm{e})$} & {$[\mathrm{YU}](1981 \mathrm{e})$} & {$[\mathrm{UN}](1991)$} & {$[\mathrm{UN}](2002)$} & & \\
\hline \multirow{5}{*}{ 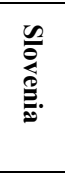 } & Population & $1,473,094$ & $1,580,010$ & $1,669,731$ & $1,831,881$ & $1,926,701$ & $1,985,406$ & $2,024,912$ & $2,065,204$ \\
\hline & Muslims \% & 0.03 & 0.07 & 0.33 & 0.91 & 1.53 & 2.42 & 2.42 & 2.42 \\
\hline & \begin{tabular}{|l|} 
Muslims \\
\end{tabular} & 442 & 1,106 & 5,510 & 16,670 & 29,479 & 48,047 & 49,003 & 49,978 \\
\hline & APGR \% & & 0.703 & 0.554 & 0.931 & 0.506 & 0.301 & 0.197 & \\
\hline & Reference & {$[\mathrm{SI}](1948 \mathrm{e})$} & {$[\mathrm{SI}](1961 \mathrm{e})$} & {$[\mathrm{SI}](1971 \mathrm{e})$} & {$[\mathrm{SI}](1981 \mathrm{e})$} & [SI](1991) & {$[\mathrm{SI}](2002)$} & & \\
\hline \multirow{4}{*}{$\stackrel{\overrightarrow{0}}{\stackrel{0}{0}}$} & Population & $48,688,176$ & $54,465,352$ & $59,165,403$ & $64,649,302$ & $68,106,159$ & $66,783,032$ & $65,780,494$ & $64,967,474$ \\
\hline & Muslims \% & 7.81 & 8.68 & 10.46 & 11.78 & 12.58 & 12.08 & 13.17 & 13.99 \\
\hline & Muslims & $3,800,918$ & $4,728,533$ & $6,189,403$ & $7,614,256$ & $8,568,130$ & $8,068,858$ & $8,661,125$ & $9,088,975$ \\
\hline & APGR \% & & 1.128 & 0.831 & 0.890 & 0.522 & -0.196 & -0.151 & \\
\hline
\end{tabular}


2.5. Greece: According to census data, the Muslim population decreased from 112,665 or $1.48 \%$ in 1951 , to 114,955 or $1.37 \%$ in 1961 , to 110,000 or $1.25 \%$ in 1971 to 160,000 or $1.66 \%$ in 1981. Recent estimates of the Muslim population increased from 98,000 or $0.90 \%$ in 2001 , to 320,000 or $2.86 \%$ in 2009 .

2.6. Kosovo: Based on census data, the Muslim population increased from 344,500 or $78.47 \%$ in 1921 , to 510,794 or $69.68 \%$ in 1948 , to 571,056 or $69.99 \%$ in 1953 , to 675,571 or $70.08 \%$ in 1961 , to 943,005 or $75.82 \%$ in 1971 , to $1,273,375$ or $80.37 \%$ in 1981 , to $1,652,262$ or $84.46 \%$ in 1991 , to $1,963,912$ or $93.52 \%$ in 2006 .

2.7. Macedonia: Based on census data, the Muslim population changed from 634,000 or $36.76 \%$ in 1904 , to 384,000 or $33.47 \%$ in 1912 , to 269,000 or $31.43 \%$ in 1921 , to 314,603 or $27.29 \%$ in 1948 , to 388,515 or $29.78 \%$ in 1953 , to 338,200 or $24.05 \%$ in 1961 , to 414,176 or $25.14 \%$ in 1971 , to 546,437 or $28.62 \%$ in 1981 to 611,326 or $30.06 \%$ in 1991 , to 581,203 or $30.04 \%$ in 1994 , to 674,015 or $33.33 \%$ in 2002 .

2.8. Montenegro: According to census data, the Muslim population changed from 55,700 or $17.89 \%$ in 1921 , to 21,834 or $5.79 \%$ in 1948 , to 32,509 or $7.74 \%$ in 1953 , to 60,410 or $12.80 \%$ in 1961 , to 106,664 or $20.14 \%$ in 1971 , to 117,286 or $20.07 \%$ in 1981 , to 130,789 or $21.25 \%$ in 1991 , to 110,034 or $17.74 \%$ in 2003 .

2.9. Romania: Religious data started being gathered since the 1992 census, which also showed that only the Turkish and Tartar minorities are mostly Muslim. The previous censuses included ethnic affiliations from which we can deduce religion. Accordingly, and based on census data, the corresponding Muslim population changed from 41,660 or $0.29 \%$ in 1930 , to 28,782 or $0.18 \%$ to 34,798 or $0.20 \%$ in 1956 , to 40,191 or $0.21 \%$ in 1966 , to 46,791 or

TABLE 3. ESTIMATE OF THE MUSLIM POPULATION IN EASTERN EUROPE FROM 1950 TO 2020.

\begin{tabular}{|c|c|c|c|c|c|c|c|c|c|}
\hline & & 1950 & 1960 & 1970 & 1980 & 1990 & 2000 & 2010 & 2020 \\
\hline \multirow{5}{*}{$\frac{\varpi 0}{0}$} & Population & $7,745,003$ & $8,190,006$ & $9,039,503$ & $9,658,500$ & $10,259,700$ & $10,053,547$ & $9,587,940$ & $9,143,897$ \\
\hline & Muslims \% & 0.23 & 0.16 & 0.19 & 0.21 & 0.31 & 0.25 & 0.25 & 0.25 \\
\hline & Muslims & 17,814 & 13,104 & 17,175 & 20,283 & 31,805 & 25,134 & 23,970 & 22,860 \\
\hline & APGR \% & & 0.560 & 0.992 & 0.665 & 0.606 & -0.203 & -0.473 & \\
\hline & Reference & {$[\mathrm{SU}](1939 \mathrm{e})$} & {$[\mathrm{SU}](1959 \mathrm{e})$} & {$[\mathrm{SU}](1970 \mathrm{e})$} & {$[\mathrm{SU}](1979 \mathrm{e})$} & {$[\mathrm{SU}](1989 \mathrm{e})$} & {$[\mathrm{UNE}](1999 \mathrm{e})$} & & \\
\hline \multirow{5}{*}{ 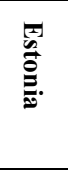 } & Population & $1,100,998$ & $1,216,003$ & $1,365,002$ & $1,472,898$ & $1,567,485$ & $1,370,335$ & $1,339,459$ & $1,309,279$ \\
\hline & Muslims \% & 0.27 & 0.27 & 0.28 & 0.37 & 0.50 & 0.12 & 0.12 & 0.12 \\
\hline & Muslims & 2,973 & 3,283 & 3,822 & 5,450 & 7,837 & 1,644 & 1,607 & 1,571 \\
\hline & APGR \% & & 0.998 & 1.163 & 0.764 & 0.624 & -1.335 & -0.228 & \\
\hline & Reference & & {$[\mathrm{SU}](1959 \mathrm{e})$} & {$[\mathrm{SU}](1970 \mathrm{e})$} & {$[\mathrm{SU}](1979 \mathrm{e})$} & {$[\mathrm{SU}](1989 \mathrm{e})$} & {$[\mathrm{UN}](2000)$} & & \\
\hline \multirow{5}{*}{ 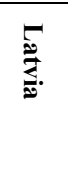 } & Population & $1,949,000$ & $2,120,977$ & $2,359,169$ & $2,511,718$ & $2,663,162$ & $2,373,770$ & $2,240,265$ & $2,114,269$ \\
\hline & Muslims \% & 0.38 & 0.38 & 0.45 & 0.52 & 0.72 & 0.29 & 0.29 & 0.29 \\
\hline & Muslims & 7,406 & 8,060 & 10,616 & 13,061 & 19,175 & 6,884 & 6,497 & 6,131 \\
\hline & APGR \% & & 0.849 & 1.070 & 0.629 & 0.587 & -1.144 & -0.577 & \\
\hline & Reference & & [SU](1959e) & \begin{tabular}{|l}
$\mathrm{SU}](1970 \mathrm{e})$ \\
\end{tabular} & {$[\mathrm{SU}](1979 \mathrm{e})$} & \begin{tabular}{|l} 
SU] $(1989 \mathrm{e})$ \\
\end{tabular} & {$[$ UNE] $(2000 \mathrm{e})$} & & \\
\hline \multirow{5}{*}{ 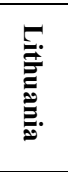 } & Population & $2,567,402$ & $2,778,552$ & $3,139,645$ & $3,413,204$ & $3,697,849$ & $3,500,819$ & $3,255,324$ & $3,027,044$ \\
\hline & Muslims \% & 0.18 & 0.18 & 0.17 & 0.14 & 0.29 & 0.08 & 0.08 & 0.08 \\
\hline & Muslims & 4,621 & 5,001 & 5,337 & 4,778 & 10,724 & 2,801 & 2,604 & 2,422 \\
\hline & APGR \% & & 0.793 & 1.229 & 0.839 & 0.804 & -0.546 & -0.724 & \\
\hline & Reference & & {$[\mathrm{SU}](1959 \mathrm{e})$} & {$[\mathrm{SU}](1970 \mathrm{e})$} & {$[\mathrm{SU}](1979 \mathrm{e})$} & {$[\mathrm{SU}](1989 \mathrm{e})$} & {$[\mathrm{UN}](2001)$} & & \\
\hline \multirow{5}{*}{$\frac{3}{0}$} & Population & $2,170,003$ & $2,740,500$ & $3,149,501$ & $3,431,998$ & $3,684,950$ & $3,514,257$ & $3,063,574$ & $2,670,688$ \\
\hline & Muslims \% & 0.09 & 0.09 & 0.11 & 0.17 & 0.28 & 0.05 & 0.05 & 0.05 \\
\hline & Muslims & 1,953 & 2,466 & 3,464 & 5,834 & 10,318 & 1,757 & 1,532 & 1,335 \\
\hline & APGR \% & & 2.362 & 1.401 & 0.863 & 0.714 & -0.473 & -1.363 & \\
\hline & Reference & & {$[\mathrm{SU}](1959 \mathrm{e})$} & {$[\mathrm{SU}](1970 \mathrm{e})$} & {$[\mathrm{SU}](1979 \mathrm{e})$} & {$[\mathrm{SU}](1989 \mathrm{e})$} & {$[\mathrm{MD}](2004)$} & & \\
\hline \multirow{5}{*}{ 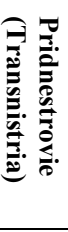 } & Population & 171,000 & 263,000 & 445,000 & 578,000 & 679,000 & 586,000 & 512,000 & 447,345 \\
\hline & Muslims \% & 0.01 & 0.01 & 0.01 & 0.01 & 0.01 & 0.01 & 0.01 & 0.01 \\
\hline & Muslims & 17 & 26 & 45 & 58 & 68 & 59 & 51 & 45 \\
\hline & APGR \% & & 4.399 & 5.400 & 2.649 & 1.624 & -1.462 & -1.341 & \\
\hline & Reference & & & & & & [PV](2004) & & \\
\hline \multirow{5}{*}{ 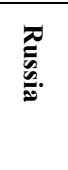 } & Population & $102,702,461$ & $119,905,701$ & $130,391,798$ & $138,655,363$ & $148,065,210$ & $146,669,828$ & $140,366,561$ & $134,334,183$ \\
\hline & Muslims \% & 5.97 & 6.11 & 7.06 & 7.43 & 8.15 & 10.14 & 10.14 & 10.14 \\
\hline & Muslims & $6,131,337$ & $7,326,238$ & $9,205,661$ & $10,302,093$ & $12,067,315$ & $14,872,321$ & $14,233,169$ & $13,621,486$ \\
\hline & APGR \% & & 1.561 & 0.842 & 0.616 & 0.659 & -0.095 & -0.438 & \\
\hline & Reference & {$[\mathrm{SU}](1939 \mathrm{e})$} & [SU](1959e) & \begin{tabular}{|l}
$\mathrm{SU}](1970 \mathrm{e})$ \\
\end{tabular} & {$[\mathrm{SU}](1979 \mathrm{e})$} & {$[$ [SU](1989e) } & {$[\mathrm{RU}](2002 \mathrm{e})$} & & \\
\hline \multirow{5}{*}{ 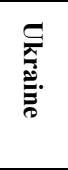 } & Population & $37,297,652$ & $42,783,010$ & $47,316,501$ & $50,043,550$ & $51,582,774$ & $48,870,139$ & $45,433,415$ & $42,238,374$ \\
\hline & Muslims \% & 1.03 & 0.30 & 0.34 & 0.38 & 0.57 & 0.91 & 0.98 & 0.98 \\
\hline & Muslims & 384,166 & 128,349 & 160,876 & 190,165 & 294,022 & 444,718 & 445,247 & 413,936 \\
\hline & APGR \% & & 1.382 & 1.012 & 0.562 & 0.303 & -0.539 & -0.727 & \\
\hline & Reference & {$[\mathrm{SU}](1939 \mathrm{e})$} & {$[\mathrm{SU}](1959 \mathrm{e})$} & {$[\mathrm{SU}](1970 \mathrm{e})$} & {$[\mathrm{SU}](1979 \mathrm{e})$} & {$[\mathrm{SU}](1989 \mathrm{e})$} & {$[\mathrm{UNE}](2001 \mathrm{e})$} & {$[\mathrm{UA}](2007 \mathrm{~s})$} & \\
\hline \multirow{4}{*}{$\stackrel{\overrightarrow{0}}{\hat{0}}$} & Population & $155,703,519$ & $179,997,749$ & $197,206,119$ & $209,765,231$ & $222,200,130$ & $216,938,695$ & $205,798,538$ & $195,285,078$ \\
\hline & Muslims \% & 4.21 & 4.16 & 4.77 & 5.03 & 5.60 & 7.08 & 7.15 & 7.20 \\
\hline & Muslims & $6,550,287$ & $7,486,528$ & $9,406,997$ & $10,541,723$ & $12,441,263$ & $15,355,317$ & $14,714,678$ & $14,069,786$ \\
\hline & APGR \% & & 1.460 & 0.917 & 0.619 & 0.578 & -0.239 & -0.526 & \\
\hline
\end{tabular}


$0.22 \%$ in 1977 , to 55,928 or $0.25 \%$ in 1992 , to 67,257 or $0.31 \%$ in 2002 .

2.10. Serbia: According to census data, the total population changed from $5,794,837$ in 1948 , to $6,162,321$ in 1953 , to $6,678,247$ in 1961 , to $7,202,915$ in 1971 , to $7,729,246$ in 1981 , to $7,822,795$ in 1991 , to $7,498,001$ in 2002. The last two censuses included religious data and both excluded Kosovo. The 1991 included Montenegro and found 468,713 Muslims, from which we extract the estimate of 130,789 Muslims in Montenegro based on the 1991 ethnic data. The previous censuses included ethnic data from which we can deduce religious affiliation, but included Kosovo. The data of the latter was extracted both from the total and Muslim population. Accordingly, the corresponding Muslim population changed from 95,800 or $3.36 \%$ in 1921 , to 92,033 or $1.59 \%$ in 1948 , to 168,928 or $2.74 \%$ in 1953 , to 173,337 or $2.60 \%$ in 1961 , to 264,200 or
$3.67 \%$ in 1971 , to 368,292 or $4.76 \%$ in 1981 , to 337,924 or $4.32 \%$ in 1991 , to 239,658 or $3.20 \%$ in 2002 .

2.11. Slovenia: Based on census data, the Muslim population changed from 927 or $0.08 \%$ in 1931, to 395 or $0.03 \%$ in 1948 , to 3,517 or $0.24 \%$ in 1953 , to 1,040 or $0.07 \%$ in 1961 , to 5,466 or $0.33 \%$ in 1971 , to 16,751 or $0.91 \%$ in 1981 , to 29,361 or $1.53 \%$ in 1991 , to 47,488 or $2.42 \%$ in 2002.

\section{MusLims In EASTERn EUROPE}

This region consists of eight countries: Belarus, Estonia, Latvia, Lithuania, Moldova, Pridnestrovie (Transnistria), Russia, and Ukraine. The total population of this region increased from 64 million in 1870 , to 156 million in 1950 , to 195 million by 2020. The related Muslim population changed from $4 \%$ in 1870 , to $4 \%$ in 1950 , to $7 \%$ by 2020 . The corresponding individual data for each country in this

TABLE 4. ESTIMATE OF THE MUSLIM POPULATION IN NORTHWESTERN EUROPE FROM 1950 TO 2020.

\begin{tabular}{|c|c|c|c|c|c|c|c|c|c|}
\hline & & 1950 & 1960 & 1970 & 1980 & 1990 & 2000 & 2010 & 2020 \\
\hline \multirow{5}{*}{ 兽 } & Population & $8,628,489$ & $9,155,060$ & $9,632,471$ & $9,827,738$ & $9,933,055$ & $10,193,094$ & $10,697,588$ & $11,227,051$ \\
\hline & Muslims \% & 0.10 & 0.80 & 1.30 & 3.60 & 4.50 & 6.00 & 6.00 & 6.00 \\
\hline & \begin{tabular}{|l|} 
Muslims \\
\end{tabular} & 8,628 & 73,240 & 125,222 & 353,799 & 446,987 & 611,586 & 641,855 & 673,623 \\
\hline & APGR \% & & 0.594 & 0.510 & 0.201 & 0.107 & 0.259 & 0.484 & \\
\hline & Reference & {$[\mathrm{KET}]$} & [KET] & {$[\mathrm{KET}]$} & {$[$ KET] } & {$[\mathrm{KET}]$} & {$[\mathrm{BE}]$} & & \\
\hline \multirow{5}{*}{ 高 } & Population & 102,236 & 109,987 & 122,026 & 129,170 & 141,846 & 146,714 & 150,092 & 153,548 \\
\hline & Muslims \% & 0.10 & 0.10 & 0.10 & 0.10 & 0.10 & 0.10 & 0.10 & 0.10 \\
\hline & \begin{tabular}{|l|} 
Muslims \\
\end{tabular} & 102 & 110 & 122 & 129 & 142 & 147 & 150 & 154 \\
\hline & APGR \% & & 0.733 & 1.044 & 0.571 & 0.941 & 0.338 & 0.228 & \\
\hline & Reference & & & & & & & [PEW] & \\
\hline \multirow{5}{*}{ 㺼 } & Population & $41,831,805$ & $45,673,851$ & $50,770,956$ & $53,949,749$ & $56,842,015$ & $59,128,075$ & $62,636,580$ & $66,353,270$ \\
\hline & Muslims \% & 0.55 & 2.00 & 3.90 & 4.60 & 7.00 & 8.00 & 10.00 & 10.00 \\
\hline & \begin{tabular}{|l|} 
Muslims \\
\end{tabular} & 230,075 & 913,477 & $1,980,067$ & $2,481,688$ & $3,978,941$ & $4,730,246$ & $6,263,658$ & $6,635,327$ \\
\hline & APGR \% & & 0.883 & 1.064 & 0.609 & 0.524 & 0.395 & 0.578 & \\
\hline & Reference & {$[\mathrm{KET}]$} & & {$[\mathrm{KET}]$} & {$[\mathrm{KET}]$} & {$[\mathrm{KET}]$} & [DOS01] & [DOS] & \\
\hline \multirow{5}{*}{$\begin{array}{l}\overline{0} \\
\frac{0}{0} \\
0\end{array}$} & Population & $2,969,000$ & $2,833,997$ & $2,953,705$ & $3,400,999$ & $3,514,643$ & $3,803,822$ & $4,589,002$ & $5,536,258$ \\
\hline & Muslims \% & 0.07 & 0.07 & 0.07 & 0.11 & 0.11 & 0.49 & 0.76 & 0.76 \\
\hline & \begin{tabular}{|l|} 
Muslims \\
\end{tabular} & 2,078 & 1,984 & 2,068 & 3,741 & 3,866 & 18,639 & 34,876 & 42,076 \\
\hline & APGR \% & & -0.464 & 0.415 & 1.420 & 0.329 & 0.794 & 1.894 & \\
\hline & Reference & & & {$[\mathrm{KET}]$} & & [IE](1991) & [IE](2002) & {$[\mathrm{IE}](2006)$} & \\
\hline \multirow{5}{*}{$\begin{array}{l}\frac{n}{a} \\
0 \\
0\end{array}$} & Population & 51,000 & 50,423 & 60,496 & 63,000 & 70,000 & 74,911 & 80,276 & 86,025 \\
\hline & Muslims \% & 0.20 & 0.20 & 0.20 & 0.20 & 0.20 & 0.20 & 0.20 & 0.20 \\
\hline & \begin{tabular}{|l|} 
Muslims \\
\end{tabular} & 102 & 101 & 121 & 126 & 140 & 150 & 161 & 172 \\
\hline & APGR \% & & -0.114 & 1.838 & 0.406 & 1.059 & 0.680 & 0.694 & \\
\hline & Reference & & & & & & & {$[\mathrm{PEW}]$} & \\
\hline \multirow{5}{*}{ 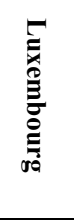 } & Population & 296,001 & 314,002 & 339,184 & 364,158 & 381,860 & 436,923 & 491,772 & 553,506 \\
\hline & Muslims \% & 0.60 & 0.60 & 0.60 & 2.60 & 2.60 & 1.37 & 1.96 & 1.96 \\
\hline & Muslims & 1,776 & 1,884 & 2,035 & 9,468 & 9,928 & 5,986 & 9,639 & 10,849 \\
\hline & APGR \% & & 0.592 & 0.774 & 0.713 & 0.476 & 1.356 & 1.190 & \\
\hline & Reference & & & [KET] & & {$[\mathrm{KET}]$} & [DOS01] & {$[\mathrm{DOS}]$} & \\
\hline \multirow{5}{*}{ 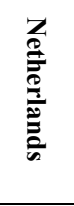 } & Population & $10,113,998$ & $11,486,631$ & $13,038,524$ & $14,149,808$ & $14,952,737$ & $15,914,751$ & $16,653,346$ & $17,426,219$ \\
\hline & Muslims \% & 0.05 & 0.05 & 1.10 & 2.80 & 4.10 & 5.50 & 5.80 & 5.80 \\
\hline & Muslims & 5,057 & 5,743 & 143,424 & 396,195 & 613,062 & 875,311 & 965,894 & $1,010,721$ \\
\hline & APGR \% & & 1.281 & 1.275 & 0.821 & 0.553 & 0.625 & 0.455 & \\
\hline & Reference & [KET] & & [KET] & [KET] & {$[\mathrm{NL}](1995)$} & [NL02](2002) & [NL02](2004) & \\
\hline \multirow{5}{*}{ 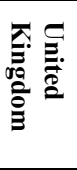 } & Population & $50,615,999$ & $52,371,995$ & $55,663,200$ & $56,314,221$ & $57,237,499$ & $58,907,407$ & $61,899,272$ & $65,043,092$ \\
\hline & Muslims \% & 0.20 & 0.20 & 1.20 & 2.20 & 2.60 & 2.71 & 4.00 & 4.00 \\
\hline & Muslims & 101,232 & 104,744 & 667,958 & $1,238,913$ & $1,488,175$ & $1,596,391$ & $2,475,971$ & $2,601,724$ \\
\hline & APGR \% & & 0.342 & 0.611 & 0.116 & 0.163 & 0.288 & 0.497 & \\
\hline & Reference & {$[\mathrm{KET}]$} & & {$[\mathrm{KET}]$} & {$[\mathrm{KET}]$} & {$[\mathrm{KET}]$} & [CIA] $(2001)$ & {$[\mathrm{UK}](2008 \mathrm{~s})$} & \\
\hline \multirow{4}{*}{$\overrightarrow{0}$} & Population & $114,608,528$ & $121,995,946$ & $132,580,562$ & $138,198,843$ & $143,073,655$ & $148,605,697$ & $157,197,928$ & \begin{tabular}{|l|}
$166,378,969$ \\
\end{tabular} \\
\hline & Muslims \% & 0.30 & 0.90 & 2.20 & 3.24 & 4.57 & 5.27 & 6.61 & 6.60 \\
\hline & \begin{tabular}{|l|} 
Muslims \\
\end{tabular} & 349,051 & $1,101,283$ & $2,921,017$ & $4,484,059$ & $6,541,242$ & $7,838,455$ & $10,392,204$ & $10,974,644$ \\
\hline & APGR \% & & 0.627 & 0.835 & 0.416 & 0.347 & 0.380 & 0.564 & \\
\hline
\end{tabular}


region is discussed below and summarized in Table 3.

3.1. Belarus: According to census data, the Muslim population changed from 3,850 or $0.08 \%$ in 1926 , to 12,921 or $0.23 \%$ in 1939 , to 13,152 or $0.16 \%$ in 1959 , to 16,733 or 0.19 in 1970 , to 20,433 or $0.21 \%$ in 1979 , to 30,998 or 0.31 in 1989 , to 25,368 or $0.25 \%$ in 1999 .

3.2. Estonia: According to census data, the Muslim population changed from 3,195 or $0.27 \%$ in 1959 , to 3,797 or $0.28 \%$ in 1970 , to 5,405 or $0.37 \%$ in 1979 , to 7,882 or 0.50 in 1989 , to 1,387 or $0.12 \%$ in 2000 .

3.3. Latvia: According to census data, the Muslim population changed from 3,879 or $0.19 \%$ in 1959 , to 5,542 or 0.23 in 1970 , to 7,443 or $0.30 \%$ in 1979 , to 12,854 or 0.72 in 1989 , to 6,984 or $0.29 \%$ in 2000 .

3.4. Lithuania: According to census data, the Muslim population changed from 4,957 or $0.18 \%$ in 1959 , to 5,276 or $0.17 \%$ in 1970 , to 4,596 or $0.14 \%$ in 1979 , to 10,751 or $0.29 \%$ in 1989 , to 2,860 or $0.08 \%$ in 2001 .

3.5. Moldova: According to census data, the Muslim population changed from 112 or $0.02 \%$ in 1926 , to 2,679 or $0.09 \%$ in 1959 , to 4,043 or $0.11 \%$ in 1970 , to 6,821 or $0.17 \%$ in 1979 , to 12,278 or 0.28 in 1989 , to 1,667 or $0.05 \%$ in 2004.

3.6. Pridnestrovie (Transnistria): This is a de facto independent nation, which is claimed by Moldova. According to census data, there are no Muslims in this region and the total population changed from 578,000 in 1979 , to 679,000 in 1989 , to 555,347 in 2004 . Data for previous years were estimated from the 1970 and 1959 census results regarding the population of the two major cities: Bender and Tiraspol. The total population of both cities was multiplied by a factor of 2.5 to estimate the total population. This factor was based on the last three censuses.

3.7. Russia: The censuses in Russia include ethnic demography, from which we can deduce religion. Accordingly, the corresponding Muslim population increased from $5,200,000$ or $5.63 \%$ in 1926 , to $6,467,681$ or $5.97 \%$ in 1939 , to $7,178,905$ or $6.11 \%$ in 1959 , to $9,185,742$ or $7.06 \%$ in 1970 , to $10,215,373$ or $7.43 \%$ in 1979 , to $11,985,439$ or $8.15 \%$ in 1989 , to $14,722,184$ or $10.14 \%$ in 2002.

3.8. Ukraine: According to census data, the Muslim population changed from 213,382 or $0.73 \%$ in 1926 , to 329,056 or $1.03 \%$ in 1939 , to 106,788 or $0.26 \%$ in 1959 , to 135,117 or 0.29 in 1970 , to 154,814 or $0.31 \%$ in 1979 , to 245,931 or 0.48 in 1989 , to 440,300 or $0.91 \%$ in 2001 . According to a 2007 DHS, this percentage increased to $0.98 \%$.

\section{MUSLIMS IN NORTHWESTERN EUROPE}

This region consists of eight countries and territories: Belgium, Channel Islands, France, Ireland, Isle of Man, Luxemburg, Netherlands, and the United Kingdom. The total population of this region increased from 75 million in 1870 , to 115 million in 1950 , to 166 million by 2020 . The related Muslim population changed from $0.01 \%$ in 1870 , to $0.3 \%$ in 1950 , to $7 \%$ by 2020 . The corresponding individual data for each country in this region is discussed below and summarized in Table 4.

4.1. Belgium: The presence of Islam started after WWII and the Muslim population increased from 8,000 or $0.1 \%$ in 1951 , to 121,000 or $1.3 \%$ in 1971 , to 350,000 or $3.6 \%$ in 1981 , to 450,000 or $4.5 \%$ in 1991 , to 628,751 or $6.0 \%$ in

TABLE 5. ESTIMATE OF THE MUSLIM POPULATION IN THE NORDIC FROM 1950 TO 2020.

\begin{tabular}{|c|c|c|c|c|c|c|c|c|c|}
\hline & & 1950 & 1960 & 1970 & 1980 & 1990 & 2000 & 2010 & 2020 \\
\hline \multirow{5}{*}{ 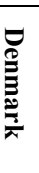 } & Population & $4,270,994$ & $4,580,999$ & $4,928,767$ & $5,123,029$ & $5,139,947$ & $5,335,385$ & $5,481,283$ & $5,631,171$ \\
\hline & Muslims \% & 0.01 & 0.01 & 0.32 & 0.32 & 1.90 & 2.00 & 3.70 & 3.70 \\
\hline & Muslims & 427 & 458 & 15,772 & 16,394 & 97,659 & 106,708 & 202,807 & 208,353 \\
\hline & APGR \% & & 0.703 & 0.734 & 0.387 & 0.033 & 0.374 & 0.270 & \\
\hline & Reference & [KET] & & [KET] & & [KET] & [DOS01] & [DOS] & \\
\hline \multirow{5}{*}{ 承 } & Population & $4,009,003$ & $4,430,001$ & $4,605,998$ & $4,779,537$ & $4,986,441$ & $5,173,368$ & $5,345,826$ & $5,524,033$ \\
\hline & Muslims \% & 0.02 & 0.02 & 0.02 & 0.02 & 0.02 & 0.02 & 0.02 & 0.02 \\
\hline & Muslims & 802 & 886 & 921 & 956 & 997 & 1,035 & 1,069 & 1,105 \\
\hline & APGR \% & & 1.004 & 0.390 & 0.371 & 0.425 & 0.369 & 0.328 & \\
\hline & Reference & & & [UN73](1970) & {$[\mathrm{UN}](1985)$} & {$[\mathrm{UN}](1990)$} & {$[\mathrm{UN}](2000)$} & & \\
\hline \multirow{5}{*}{ 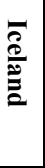 } & Population & 142,998 & 175,998 & 204,101 & 228,160 & 254,793 & 281,085 & 329,279 & 385,736 \\
\hline & Muslims \% & 0.01 & 0.01 & 0.01 & 0.01 & 0.06 & 0.06 & 0.38 & 0.38 \\
\hline & Muslims & 14 & 18 & 20 & 23 & 153 & 169 & 1,251 & 1,466 \\
\hline & APGR \% & & 2.098 & 1.492 & 1.121 & 1.110 & 0.987 & 1.595 & \\
\hline & Reference & & & {$[\mathrm{KET}]$} & & & [DOS01] & [DOS] & \\
\hline \multirow{5}{*}{ 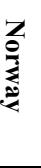 } & Population & $3,265,000$ & $3,580,998$ & $3,877,383$ & $4,085,621$ & $4,241,485$ & $4,483,961$ & $4,855,315$ & $5,257,424$ \\
\hline & Muslims \% & 0.13 & 0.13 & 0.13 & 0.13 & 1.20 & 1.69 & 2.05 & 2.05 \\
\hline & Muslims & 4,245 & 4,655 & 5,041 & 5,311 & 50,898 & 75,779 & 99,534 & 107,777 \\
\hline & APGR \% & & 0.928 & 0.798 & 0.525 & 0.375 & 0.557 & 0.799 & \\
\hline & Reference & & & {$[\mathrm{KET}]$} & & {$[$ KET] } & {$[\mathrm{NO}](2005)$} & {$[\mathrm{NO}](2009)$} & \\
\hline \multirow{5}{*}{ 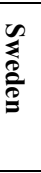 } & Population & $7,014,001$ & $7,480,001$ & $8,042,839$ & $8,310,467$ & $8,558,829$ & $8,860,162$ & $9,293,026$ & $9,747,038$ \\
\hline & Muslims \% & 0.01 & 0.01 & 0.20 & 0.30 & 1.20 & 3.41 & 5.38 & 5.38 \\
\hline & Muslims & 701 & 748 & 16,086 & 24,931 & 102,706 & 302,132 & 499,965 & 524,391 \\
\hline & APGR \% & & 0.645 & 0.728 & 0.328 & 0.295 & 0.347 & 0.478 & \\
\hline & Reference & [KET] & & [KET] & {$[\mathrm{KET}]$} & {$[\mathrm{KET}]$} & [DOS01] & [DOS] & \\
\hline \multirow{4}{*}{$\begin{array}{l}\overrightarrow{0} \\
\stackrel{\vec{\theta}}{\Xi}\end{array}$} & Population & $18,701,996$ & $20,247,997$ & $21,659,088$ & $22,526,814$ & $23,181,495$ & $24,133,961$ & $25,304,729$ & $26,545,401$ \\
\hline & Muslims \% & 0.03 & 0.03 & 0.17 & 0.21 & 1.09 & 2.01 & 3.18 & 3.18 \\
\hline & Muslims & 6,189 & 6,765 & 37,840 & 47,615 & 252,413 & 485,821 & 804,627 & 843,092 \\
\hline & APGR \% & & 0.797 & 0.676 & 0.394 & 0.287 & 0.403 & 0.475 & \\
\hline
\end{tabular}


2005.

4.2. Channel Islands: By 2005, Muslims constituted $0.1 \%$ of the total population.

4.3. France: Estimates for the Muslim population increased from less than 1,000 or $0.01 \%$ before 1900 , to 6,000 or $0.02 \%$ in 1912 , to 100,000 or $0.26 \%$ in 1920 , to 120,000 in 1924 , the decreased to 70,000 or $0.17 \%$ in 1936 , then increased to 230,000 or $0.55 \%$ in 1952 , to one million or $2 \%$ in $1960 \mathrm{~s}$, to two million or $3.9 \%$ in 1975 , to 2.5 million or $4.6 \%$ in 1981 , to four million or $7 \%$ in 1991 , to 5 million or $8 \%$ in 2001, to six million or $10 \%$ in 2009 .

4.4. Ireland: In 1971 the Muslim population was 2,000 or $0.07 \%$ of the total population. Based on census data, the Muslim population increased from 9 or less than $0.01 \%$ in 1901 , to 3,875 or $0.11 \%$ in 1991 , to 19,147 or $0.49 \%$ in 2002 , to 32,539 or $0.76 \%$ in 2006 .

4.5. Isle of Man: By 2005, Muslims constituted $0.2 \%$ of the total population.

4.6. Luxembourg: Estimates for the Muslim population changed from 2,000 or $0.6 \%$ in 1971 , to 10,000 or $2.6 \%$ in 1991 , to 6,000 or $1.37 \%$ in 2001 , to 9,000 or $1.96 \%$ in 2009 .

4.4. Netherlands: Estimates for the Muslims population increased from 5,000 or $0.05 \%$ in 1951 , to 132,000 or $1.1 \%$ in 1971 , to 400,000 or $2.8 \%$ in 1981 , to 450,000 or $3 \%$ in 1991 , to 626,000 or $4.1 \%$ in 1995 , to 890,000 or $5.5 \%$ in 2002 , to 920,000 or $5.7 \%$ in 2003 to 945,000 or $5.8 \%$ in 2004.

4.7. The United Kingdom: Estimates for the Muslim population increased from 50,000 or $0.1 \%$ in 1939 , to 100,000 or $0.2 \%$ in 1951 , to 750,000 or $1.2 \%$ in 1971 , to 1.25 million or $2.2 \%$ in 1981 , to 1.5 million or $2.6 \%$ in 1991 . According to the 2001 census, the total population was $58,789,187$, out of which $1,591,000$ or $2.71 \%$ were Muslims. The census also revealed that the population of England and

TABLE 6. ESTIMATE OF THE MUSLIM POPULATION IN CENTRAL EUROPE FROM 1950 TO 2020.

\begin{tabular}{|c|c|c|c|c|c|c|c|c|c|}
\hline & & 1950 & 1960 & 1970 & 1980 & 1990 & 2000 & 2010 & 2020 \\
\hline \multirow{5}{*}{$\underset{2}{\stackrel{2}{a}}$} & Population & $6,936,445$ & $7,042,634$ & $7,465,908$ & $7,548,798$ & $7,670,513$ & $8,004,712$ & $8,387,491$ & $8,788,574$ \\
\hline & Muslims \% & 0.12 & 0.12 & 0.12 & 1.02 & 2.04 & 4.22 & 4.22 & 4.22 \\
\hline & Muslims & 8,324 & 8,451 & 8,959 & 76,998 & 156,478 & 337,799 & 353,952 & 370,878 \\
\hline & APGR \% & & 0.152 & 0.585 & 0.110 & 0.160 & 0.427 & 0.468 & \\
\hline & Reference & & & [UN73](1971) & [UN88](1981) & {$[\mathrm{UN}](1991)$} & {$[\mathrm{UN}](2001)$} & & \\
\hline \multirow{5}{*}{ 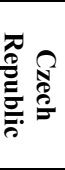 } & Population & $8,924,882$ & $9,545,911$ & $9,800,973$ & $10,283,564$ & $10,303,292$ & $10,224,397$ & $10,410,786$ & $10,600,573$ \\
\hline & Muslims \% & 0.01 & 0.01 & \begin{tabular}{|l|}
0.01 \\
\end{tabular} & 0.01 & 0.20 & 0.20 & 0.20 & 0.20 \\
\hline & Muslims & 892 & 955 & 980 & 1,028 & 20,607 & 20,449 & 20,822 & 21,201 \\
\hline & APGR \% & & 0.675 & 0.264 & 0.482 & 0.019 & -0.077 & 0.181 & \\
\hline & Reference & & & [KET] & & & {$[\mathrm{CZ}]$} & & \\
\hline \multirow{5}{*}{ Q } & \begin{tabular}{|l|} 
Population \\
\end{tabular} & $68,376,002$ & $72,814,899$ & $78,169,287$ & $78,288,577$ & $79,433,024$ & $82,074,780$ & $82,056,775$ & $82,038,774$ \\
\hline & Muslims \% & 0.03 & 0.03 & 1.50 & 2.20 & 3.10 & 3.90 & 5.22 & 5.22 \\
\hline & Muslims & 20,513 & 21,844 & $1,172,539$ & $1,722,349$ & $2,462,424$ & $3,200,916$ & $4,283,364$ & $4,282,424$ \\
\hline & APGR \% & & 0.631 & 0.712 & 0.015 & 0.145 & 0.328 & -0.002 & \\
\hline & Reference & {$[\mathrm{KET}]$} & & [KET] & {$[$ KET $]$} & {$[$ [KET] } & [DOS01] & [DOS] & \\
\hline \multirow{5}{*}{ 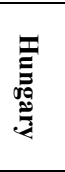 } & Population & $9,338,000$ & $9,984,003$ & $10,337,003$ & $10,707,472$ & $10,364,840$ & $10,214,758$ & $9,973,141$ & $9,737,239$ \\
\hline & Muslims \% & 0.04 & 0.03 & 0.05 & 0.03 & 0.03 & 0.03 & 0.03 & 0.03 \\
\hline & Muslims & 3,735 & 2,995 & 5,169 & 3,212 & 3,109 & 3,064 & 2,992 & 2,921 \\
\hline & APGR \% & & 0.671 & 0.348 & 0.353 & -0.325 & -0.146 & -0.239 & \\
\hline & Reference & [KET] & & [KET] & & & {$[\mathrm{HU}](2001)$} & & \\
\hline \multirow{5}{*}{ 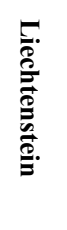 } & Population & 13,757 & 16,628 & 21,350 & 26,000 & 29,000 & 32,673 & 36,190 & 40,085 \\
\hline & Muslims \% & 0.04 & 0.04 & 0.04 & 1.67 & 2.37 & 4.78 & 4.78 & 4.78 \\
\hline & Muslims & 6 & 7 & 9 & 434 & 687 & 1,562 & 1,730 & 1,916 \\
\hline & APGR \% & & 1.913 & 2.531 & 1.990 & 1.098 & 1.200 & 1.028 & \\
\hline & Reference & & & [LI] $(1970)$ & [LI] $(1980)$ & {$[\mathrm{LI}](1990)$} & {$[\mathrm{LI}](2000)$} & & \\
\hline \multirow{5}{*}{$\frac{\overparen{0}}{\stackrel{0}{0}}$} & \begin{tabular}{|l|} 
Population \\
\end{tabular} & $24,824,013$ & $29,637,553$ & $32,664,156$ & $35,574,153$ & $38,110,783$ & $38,432,879$ & $38,038,094$ & $37,647,364$ \\
\hline & Muslims \% & 0.05 & 0.05 & 0.05 & 0.05 & 0.01 & 0.01 & 0.07 & 0.07 \\
\hline & Muslims & 12,412 & 14,819 & 16,332 & 17,787 & 3,811 & 3,843 & 26,627 & 26,353 \\
\hline & APGR \% & & 1.788 & 0.977 & 0.857 & 0.691 & 0.084 & -0.103 & \\
\hline & \begin{tabular}{|l|} 
Reference \\
\end{tabular} & & [KET] & \begin{tabular}{|l|} 
KET] \\
\end{tabular} & & & [DOS01] & [DOS] & \\
\hline \multirow{5}{*}{$\begin{array}{l}\frac{\infty}{0} \\
\frac{0}{20} \\
\frac{0}{2}\end{array}$} & \begin{tabular}{|l|} 
Population \\
\end{tabular} & $3,463,443$ & $4,144,899$ & $4,528,460$ & $4,976,397$ & $5,256,170$ & $5,378,589$ & $5,411,640$ & $5,444,894$ \\
\hline & Muslims \% & 0.01 & 0.01 & 0.01 & 0.01 & 0.09 & 0.09 & 0.09 & 0.09 \\
\hline & Muslims & 346 & 414 & 453 & 498 & 4,731 & 4,841 & 4,870 & 4,900 \\
\hline & APGR \% & & 1.812 & 0.889 & 0.948 & 0.548 & 0.230 & 0.061 & \\
\hline & Reference & & & [KET] & & & & [DOS07] & \\
\hline \multirow{5}{*}{ 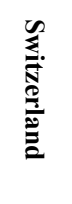 } & Population & $4,692,633$ & $5,328,229$ & $6,181,179$ & $6,319,057$ & $6,714,629$ & $7,184,177$ & $7,594,561$ & $8,028,387$ \\
\hline & Muslims \% & 0.05 & 0.05 & 0.26 & 0.89 & 2.21 & 4.26 & 4.26 & 4.26 \\
\hline & Muslims & 2,346 & 2,664 & 16,071 & 56,240 & 148,393 & 306,046 & 323,528 & 342,009 \\
\hline & APGR $\%$ & & 1.278 & 1.496 & 0.221 & 0.609 & 0.678 & 0.557 & \\
\hline & Reference & & [UN64](1960) & [UN73](1970) & {$[\mathrm{CH}](1980)$} & {$[\mathrm{CH}](1990)$} & {$[\mathrm{CH}](2000)$} & & \\
\hline \multirow{4}{*}{$\stackrel{\overrightarrow{0}}{\overrightarrow{0}}$} & \begin{tabular}{|l|} 
Population \\
\end{tabular} & $126,569,175$ & $138,514,756$ & $149,168,316$ & $153,724,018$ & $157,882,251$ & $161,546,965$ & $161,908,678$ & $162,325,891$ \\
\hline & Muslims \% & 0.04 & 0.04 & 0.82 & 1.22 & 1.77 & 2.40 & 3.10 & 3.11 \\
\hline & Muslims & 48,574 & 52,149 & $1,220,512$ & $1,878,546$ & $2,800,240$ & $3,878,520$ & $5,017,885$ & $5,052,603$ \\
\hline & APGR \% & & 0.906 & 0.744 & 0.301 & 0.267 & 0.230 & 0.022 & \\
\hline
\end{tabular}


Wales [EW] was $52,041,916$ out of which $1,546,626$ or $2.97 \%$ were Muslims, the population of Scotland [SQ] was $5,062,000$, out of which 42,600 or $0.53 \%$ were Muslims, and the population of Northern Ireland [ND] was 1,685,267, out of which 1,943 or $0.12 \%$ were Muslims. Another official statistics [UK] estimates that the Muslim population in the UK increased from $1,870,000$ in 2004 , to $2,017,000$ in 2005 , to $2,142,000$ in 2006 , to $2,327,000$ in 2007 , to $2,422,000$ in 2008 , reaching $4.00 \%$ of the total British population, according to the same source. Thus, the average annual growth rate of the Muslim population in the UK between 2004 and 2008 was $6.68 \%$, which is ten times the rate of increase of the total population during the same period, according to [UK]. This caused the percentage of Muslims in the UK to rise from $2.70 \%$ in 2001 (census year) to $4.00 \%$ in 2008; about 0.2 percentage point per year.

\section{MUSLIMS IN THE NORDIC}

This region consists of five countries: Denmark, Finland, Iceland, Norway, and Sweden. The total population of this region increased from 10 million in 1870 , to 19 million in 1950 , to 27 million by 2020 . The related Muslim population remained less than $0.1 \%$ until 1960, and reached 3\% in 2010. The corresponding individual data for each country in this region is discussed below and summarized in Table 5 .

5.1. Denmark: The Muslim population increased from few hundreds or about $0.01 \%$ in 1950 , to 16,000 or $0.32 \%$ in 1971 , to 100,000 or $1.9 \%$ in 1991 , to 106,000 or $2 \%$ in 2001 , to 210,000 or $3.7 \%$ in 2009 .

5.2. Finland: According to census data, the percentage of the Muslim population with respect to the total population remained almost constant at $0.02 \%$. The number of Muslims was 823 in 1970; 787 in 1985; 810 in 1990; and 1,199 in 2000 .

5.3. Iceland: Estimates of the Muslim population

TABLE 7. ESTIMATE OF THE MUSLIM POPULATION IN SOUTHWESTERN EUROPE FROM 1950 TO 2020.

\begin{tabular}{|c|c|c|c|c|c|c|c|c|c|}
\hline & & 1950 & 1960 & 1970 & 1980 & 1990 & 2000 & 2010 & 2020 \\
\hline \multirow{5}{*}{$\frac{3}{30}$} & Population & 5,664 & 11,000 & 27,000 & 35,000 & 57,000 & 65,908 & 87,777 & 116,903 \\
\hline & Muslims \% & 0.01 & 0.01 & 0.01 & 0.01 & 2.99 & 2.99 & 2.35 & 2.35 \\
\hline & Muslims & 1 & 1 & 3 & 4 & 1,704 & 1,971 & 2,063 & 2,747 \\
\hline & APGR \% & & 6.863 & 9.395 & 2.629 & 4.998 & \begin{tabular}{|r|}
1.463 \\
\end{tabular} & 2.907 & \\
\hline & Reference & & & {$[\mathrm{KET}]$} & & & [DOS01] & [DOS] & \\
\hline \multirow{5}{*}{ 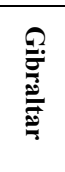 } & Population & 21,000 & 24,502 & 26,833 & 30,000 & 28,000 & 27,118 & 29,337 & 31,737 \\
\hline & Muslims \% & 8.06 & 8.06 & 8.06 & 8.02 & 6.93 & 4.01 & 4.01 & 4.01 \\
\hline & \begin{tabular}{|l|} 
Muslims \\
\end{tabular} & 1,693 & 1,975 & 2,163 & 2,406 & 1,940 & 1,087 & 1,176 & 1,273 \\
\hline & \begin{tabular}{|l|} 
APGR $\%$ \\
\end{tabular} & & 1.554 & 0.913 & 1.122 & -0.688 & -0.320 & 0.790 & \\
\hline & Reference & & & {$[$ UN73](1970) } & [UN83](1981) & {$[\mathrm{UN}](1991)$} & {$[\mathrm{UN}](2001)$} & & \\
\hline \multirow{5}{*}{$\overrightarrow{\frac{\overrightarrow{0}}{4}}$} & Population & $46,366,769$ & $49,510,848$ & $53,359,255$ & $56,307,276$ & $56,997,717$ & $57,115,970$ & $60,097,564$ & $63,234,805$ \\
\hline & Muslims \% & 0.01 & 0.09 & 0.09 & 0.09 & 1.70 & 1.70 & 2.10 & 2.10 \\
\hline & \begin{tabular}{|l|} 
Muslims \\
\end{tabular} & 4,637 & 44,560 & 48,023 & 50,677 & 968,961 & 970,971 & $1,262,049$ & $1,327,931$ \\
\hline & APGR \% & & 0.658 & 0.751 & 0.539 & 0.122 & 0.021 & 0.510 & \\
\hline & Reference & {$[\mathrm{KET}]$} & & [KET] & & & [DOS01] & [DOS] & \\
\hline \multirow{5}{*}{$\underset{3}{2}$} & Population & 311,997 & 312,001 & 302,709 & 324,126 & 360,126 & 388,906 & 409,999 & 432,236 \\
\hline & Muslims \% & 0.01 & 0.01 & 0.01 & 0.01 & 0.64 & 0.64 & 0.75 & 0.75 \\
\hline & \begin{tabular}{|l|} 
Muslims \\
\end{tabular} & 31 & 31 & 30 & 32 & 2,305 & 2,489 & 3,075 & 3,242 \\
\hline & APGR \% & & 0.000 & -0.302 & 0.686 & 1.059 & 0.772 & 0.530 & \\
\hline & Reference & [KET] & & & & & [DOS01] & {$[\mathrm{DOS}]$} & \\
\hline \multirow{5}{*}{ 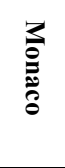 } & Population & 19,242 & 20,442 & 23,042 & 25,029 & 30,000 & 33,268 & 32,915 & 32,565 \\
\hline & Muslims \% & 1.59 & 1.59 & 1.59 & 1.59 & 2.16 & 2.17 & 1.82 & 1.82 \\
\hline & Muslims & 306 & 325 & 366 & 398 & 648 & 722 & 599 & 593 \\
\hline & APGR \% & & 0.607 & 1.204 & 0.831 & 1.828 & 1.039 & -0.107 & \\
\hline & Reference & & & & {$[\mathrm{MC}](1982 \mathrm{e})$} & {$[\mathrm{MC}](1990 \mathrm{e})$} & {$[\mathrm{MC}](2000 \mathrm{e})$} & {$[\mathrm{MC}](2008 \mathrm{e})$} & \\
\hline \multirow{5}{*}{ 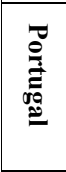 } & Population & $8,405,000$ & $8,857,723$ & $8,680,437$ & $9,766,315$ & $9,979,313$ & $10,226,124$ & $10,732,357$ & $11,263,651$ \\
\hline & Muslims \% & 0.01 & 0.01 & 0.01 & 0.06 & 0.11 & 0.14 & 0.14 & 0.14 \\
\hline & Muslims & 841 & 886 & 868 & 5,860 & 10,977 & 14,317 & 15,025 & 15,769 \\
\hline & APGR \% & & 0.526 & -0.202 & 1.186 & 0.216 & 0.245 & 0.484 & \\
\hline & Reference & & & {$[$ UN79](1970) } & [UN88](1981) & {$[\mathrm{UN}](1991)$} & {$[\mathrm{UN}](2001)$} & & \\
\hline \multirow{5}{*}{ 胥 } & Population & 15,000 & 9,796 & 19,149 & 21,000 & 23,000 & 26,941 & 32,423 & 39,022 \\
\hline & Muslims \% & 0.01 & 0.01 & 0.01 & 0.01 & 0.05 & 0.05 & 0.05 & 0.05 \\
\hline & \begin{tabular}{|l|} 
Muslims \\
\end{tabular} & 2 & 1 & 2 & 2 & 12 & 13 & 16 & 20 \\
\hline & APGR \% & & -4.171 & 6.933 & 0.927 & 0.914 & 1.594 & 1.870 & \\
\hline & Reference & & & [KET] & & & [DOS1] & {$[\mathrm{DOS}]$} & \\
\hline \multirow{5}{*}{ 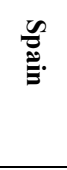 } & Population & $28,008,746$ & $30,455,156$ & $33,778,659$ & $37,526,910$ & $38,839,282$ & $40,264,336$ & $45,316,586$ & $51,002,777$ \\
\hline & Muslims \% & 0.01 & 0.01 & 0.27 & 0.27 & 0.90 & 1.75 & 2.60 & 2.60 \\
\hline & Muslims & 2,801 & 3,046 & 91,202 & 101,323 & 349,554 & 704,626 & $1,178,231$ & $1,326,072$ \\
\hline & APGR \% & & 0.841 & 1.041 & 1.058 & 0.344 & 0.361 & 1.189 & \\
\hline & Reference & {$[\mathrm{KET}]$} & & {$[$ KET $]$} & & {$[\mathrm{KET}]$} & [DOS01] & [DOS] & \\
\hline \multirow{4}{*}{$\stackrel{\overrightarrow{0}}{\stackrel{0}{0}}$} & Population & $83,153,418$ & $89,201,468$ & $96,217,084$ & $104,035,656$ & $106,314,438$ & $108,148,571$ & $116,738,958$ & $126,153,695$ \\
\hline & Muslims \% & 0.01 & 0.06 & 0.15 & 0.15 & 1.26 & 1.57 & 2.11 & 2.12 \\
\hline & \begin{tabular}{|l|} 
Muslims \\
\end{tabular} & 10,310 & 50,824 & 142,658 & 160,701 & $1,336,101$ & $1,696,196$ & $2,462,235$ & $2,677,646$ \\
\hline & APGR \% & & 0.705 & 0.760 & 0.784 & 0.217 & 0.171 & 0.767 & \\
\hline
\end{tabular}


increased from less than $0.01 \%$ in the $1970 \mathrm{~s}$, to 164 or $0.06 \%$ in 2001 , to 1,200 or $0.38 \%$ in 2009 .

5.4. Norway: Estimates of the Muslim population increased from 5,000 or $0.13 \%$ in 1971 , to 50,000 or $1.2 \%$ in 1991. According to official statistics, the Muslim population changed from 76,621 or $1.69 \%$ in 2005 , to 72,023 or $1.59 \%$ in 2006 , to 79,068 or $1.75 \%$ in 2007 , to 83,684 or $1.85 \%$ in 2008 , to 92,744 or $2.05 \%$ in 2009 .

5.5. Sweden: Estimates of the Muslim population increased from 1,000 or $0.01 \%$ in 1951 , to 17,000 or $0.2 \%$ in 1971 , to 25,000 or $0.3 \%$ in 1980 , to 100,000 or $1.2 \%$ in 1991 , to 300,000 or $3.41 \%$ in 2001 , to 500,000 or $5.38 \%$ in 2009.

\section{Muslims in CENTRAL EuROPE}

This region consists of eight countries: Austria, Czech Republic, Germany, Hungary, Liechtenstein, Poland, Slovakia, and Switzerland. The total population of this region increased from 69 million in 1870 , to 127 million in 1950 , to 162 million by 2020 . The related Muslim population remained less than $0.1 \%$ until 1960 , and reached $3 \%$ in 2010 . The corresponding individual data for each country in this region is discussed below and summarized in Table 4.5 .

6.1. Austria: According to census data, the Muslim population has increased from 9,162 or $0.12 \%$ in 1971 , to 76,939 or $1.02 \%$ in 1981 , to 158,776 or $2.04 \%$ in 1991 , to 338,988 or $4.22 \%$ in 2001 .

6.2. Czech Republic: Estimates for the Muslim population increased from 1,000 or $0.01 \%$ in 1971 , to 20,000 or $0.2 \%$ in 2006 .

6.3. Germany: Estimates for the Muslim population increased from 1,000 or less than $0.01 \%$ in 1920 , to 20,000 or $0.03 \%$ in 1951 , to $1,150,000$ or $1.5 \%$ in 1971 , to 1.8 million or $2.9 \%$ in 1981 , to 2.5 million or $3.1 \%$ in 1991 , to 3.2 million or $3.9 \%$ in 2001 , to 4.3 million or $5.22 \%$ in 2009 .

6.4. Hungary: Estimates for the Muslim population increased from 3,300 or $0.04 \%$ in 1949 to 5,000 or $0.05 \%$ in 1971. According to the 2001 census], the total Hungarian population was $10,198,315$, out of which 3,201 or $0.03 \%$ were Muslim.

6.5. Liechtenstein: Based on census data, the Muslim population increased from eight or $0.04 \%$ in 1970 , to 421 or $1.67 \%$ in 1980 , to 689 or $2.37 \%$ in 1990 , to 1,593 or $4.78 \%$ in 2000 .

6.6. Poland: Estimates of the Muslim population changed from 11,000 or $0.05 \%$ in 1963 , to 15,000 or $0.05 \%$ in 1971 , to 5,123 or $0.01 \%$ in 2001 , to 25,000 or $0.07 \%$ in 2009 .

6.7. Slovakia: Estimates of the Muslim population increased from 1,000 or $0.01 \%$ in 1971 , to 5,000 or $0.09 \%$ in 2007 .

6.8. Switzerland: Based on census data, the Muslim population grew from 2,703 or $0.05 \%$ in 1960 , to 16,353 or $0.26 \%$ in 1970 , to 56,600 or $0.89 \%$ in 1980 , to 152,200 or $2.21 \%$ in 1990 , to 310,807 or $4.26 \%$ in 2000 .
Gibraltar, Malta, Monaco, Portugal, San Marino, and Spain. The total population of this region increased from 47 million in 1870 , to 83 million in 1950 , to 126 million by 2020 . The related Muslim population remained less than $0.1 \%$ until 1960, and reached $2 \%$ in 2010. The corresponding individual data for each country in this region is discussed below and summarized in Table 7 .

7.1. Andorra: Estimates of the Muslim population changed from none in 1971 , to 2,000 or $2.99 \%$ in 2001 , to 2,000 or 2.35 in 2009 .

7.3. Gibraltar: According to census data, the Muslim population increased from 1,989 or $8.06 \%$ in 1970 , to 2,124 or $8.02 \%$ in 1981 , then decreased to 1,850 or $6.93 \%$ in 1991 , to 1,102 or $4.01 \%$ in 2001 .

7.2. Italy: Muslims started migrating to Italy after World War II, and increased from 50,000 or $0.09 \%$ in 1971 , to 400,000 or $0.7 \%$ in 1991 , to one million or $1.7 \%$ in 2001 , to 1.25 million or $2.1 \%$ in 2009 .

7.4. Malta: Estimates for the Muslim population increased from less than $0.01 \%$ in 1974 , to 2,500 or $0.64 \%$ in 2001 , to 3,000 or $0.75 \%$ in 2009 .

7.5. Monaco: According to census data, the total population changed from 27,063 in 1982 , to 29,972 in 1990 , to 32,020 in 2000 , to 31,109 in 2008 . These censuses included data on nationalities residing in Monaco, from which we can deduce religion. In our estimate only the following nationalities were considered Muslim: Algeria, Egypt, Iran, Morocco, Senegal, Syria, Tunisia, and Turkey. Accordingly, the Muslim population changed from 430 or $1.59 \%$ in 1982 , to 647 or $2.16 \%$ in 1990 , to 694 or $2.17 \%$ in 2000 , to 565 or $1.82 \%$ in 2008 .

7.6. Portugal: Based on census data, the Muslim population increased from 365 or less than $0.01 \%$ in 1970 , to 4,335 or $0.06 \%$ in 1981 , to 9,134 or $0.11 \%$ in 1991 , to 12,014 or $0.14 \%$ in 2001 . According to the 2001 census, the Muslim population was distributed as follows:

- North Region: 835 or $0.03 \%$ out of 3,042,345;

- Center Region: 638 or $0.03 \%$ out of $1,996,009$;

- Lisbon Region: 9,600 or $0.42 \%$ out of $2,265,629$ inhabitants;

- Alentejo Region: 219 or $0.03 \%$ out of 669,940 inhabitants;

- Algarve Region: 630 or $0.19 \%$ out of 337,486 inhabitants;

- Azores Islands: 19 or $0.01 \%$ out of 189,996 inhabitants;

- Madeira Islands: 73 or $0.04 \%$ out of 198,110 inhabitants.

7.7. San Marino: Estimates of the Muslim population changed from none in $1970 \mathrm{~s}$, a small number or $0.05 \%$ in 2001 and 2009.

7.8. Spain: Estimates of the Muslim population increased from less than $0.01 \%$ before 1950 , to 90,000 or $0.27 \%$ in 1971 , to 350,000 or $0.9 \%$ in 1991 , to 700,000 or $1.75 \%$ in 2001 , to 1.2 million or $2.60 \%$ in 2009 .

\section{SUMMARY}

A summary of the Muslim population change in Europe from 1950 to 2020 is presented in Table 6. Accordingly,

This region consists of eight countries: Andorra, Italy, 
while the total European population increased from 281 million in 1870 , to 547 million in 1950 to 742 million by 2020, the related Muslim population increased from $2 \%$ in 1870 and 1950 to $6 \%$ by 2020 . In addition, the fraction of World Muslims living in Europe has been between 2\% and $3 \%$ since 1950 . A color coded map of Asia illustrating the presence of Muslims in each country is presented in Figure 6 . The value of pure white color is 255 , while pure black is 0 . Given a percentage of Muslims $\mathrm{p}$, the color was chosen as $255-2.55 \mathrm{p}$. Thus, the darker the region is, the higher the percentage of Muslims in the corresponding country.

TABLE 8. ESTIMATE OF THE MUSLIM POPULATION IN EUROPE FROM 1950 TO 2020.

\begin{tabular}{|c|c|c|c|c|c|c|c|c|c|}
\hline & & 1950 & 1960 & 1970 & 1980 & 1990 & 2000 & 2010 & 2020 \\
\hline \multirow{6}{*}{ 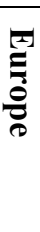 } & Population & $547,424,812$ & $604,423,268$ & $655,996,572$ & $692,899,864$ & $720,758,128$ & $726,156,921$ & $732,729,325$ & $741,656,508$ \\
\hline & Muslims \% & 1.97 & 2.22 & 3.04 & 3.57 & 4.43 & 5.14 & 5.74 & 5.76 \\
\hline & Muslims & $10,765,329$ & $13,426,084$ & $19,918,426$ & $24,726,900$ & $31,939,389$ & $37,323,169$ & $42,052,753$ & $42,706,747$ \\
\hline & CAPGR \% & & 0.995 & 0.822 & 0.549 & 0.395 & 0.075 & 0.090 & \\
\hline & MAPGR \% & & 2.233 & 4.023 & 2.186 & 2.593 & 1.570 & 1.200 & \\
\hline & Mus. Ratio\% & 2.49 & 2.49 & 2.83 & 2.71 & 2.73 & 2.57 & 2.44 & 2.08 \\
\hline \multirow{5}{*}{$\begin{array}{l}\sum \\
0 \\
2\end{array}$} & Population & $2,537,241,236$ & $3,034,626,491$ & $3,700,897,698$ & $4,456,005,072$ & $5,311,251,139$ & $6,137,637,624$ & $6,932,088,715$ & $7,881,482,130$ \\
\hline & Muslims \% & 17.06 & 17.77 & 19.02 & 20.45 & 22.07 & 23.65 & 24.86 & 26.01 \\
\hline & Muslims & $432,961,301$ & $539,240,373$ & $703,760,495$ & $911,165,259$ & $1,171,946,661$ & $1,451,537,157$ & $1,723,607,136$ & $2,050,085,347$ \\
\hline & WAPGR \% & & 1.806 & 2.005 & 1.874 & 1.771 & 1.457 & 1.225 & \\
\hline & MAPGR \% & & 2.219 & 2.699 & 2.617 & 2.549 & 2.163 & 1.733 & \\
\hline
\end{tabular}


Since the 1950s, the continent annual population growth (APGR) has been decreasing constantly, from $1 \%$ to $0.1 \%$ in the 2010s, which is the lowest among all continents. The corresponding APGR for the Muslim population in this continent is currently ten times of the continent's APGR. Thus, the percentage of Muslims is expected to continue to rise.

\section{REFERENCES}

[1] "Albania Demographic and Health Survey 2008-09," Institute of Statistics, Institute of Public Health, Tirana, Albania, and ICF Macro, Calverton, Maryland, USA, March 2010.

[2] "Statistical Yearbook 2009," Federal Office of Statistics, Sarajevo, Federation of Bosnia and Herzegovina, Sarajevo, 2009.

[3] J. Hertogen "In België wonen 628.751 moslims," Indymedia, September 12, 2008

[4] "The tragedy of Islam in Belarus," Kavkaz Center, February 9, 2007.

[5] "Languages and Religions - Data, Indicators," Federal Population Census, Swiss Federal Statistical Office, Neuchâtel, Switzerland, 2009.

[6] "The World Factbook," Central Intelligence Agency, July 2009.

[7] C. O'Connor, "The Czech Muslim community: A beacon of piety in a predominantly atheist country," Czechs Today, August 16, 2006.

[8] "2009 Report on International Religious Freedom," Bureau of Democracy, Human Rights, and Labor, Under Secretary for Democracy and Global Affairs, United States Department of State, October 2009

[9] "2007 Report on International Religious Freedom," Bureau of Democracy, Human Rights, and Labor, Under Secretary for Democracy and Global Affairs, United States Department of State, September 2007.

[10] "Census 2001 - National report for England and Wales," Office for National Statistics, May 2003.

[11] "Census of Gibraltar 2001," Statistics Office, Government of Gibraltar, 2007.

[12] "Population of the Republic of Croatia According to Religion and Ethnicity, 1880 - 1991, by Settlementes," Central Bureau of Statistics, Zagreb, Republic of Croatia, December 1998.

[13] ]"Population census 2001, Volume 18: Demographic data," Hungarian Central Statistical Office, July 2004.

[14] "Census 2006 - Volume 13: Religion," Central Statistics Office, Government of Ireland, Stationery Office, Dublin, Ireland, November 2007 (ISBN 0-7557-7211-3).

[15] A. Kettani, "الثــيوعي المعسـكر فـي المســلمون" (Muslims in Communist Countries)," Organization of Islamic Conference, Mecca, Saudi Arabia, 1973.

[16] A. Kettani, "و ؤمريكـا أوروبـا فـي المســلمون (Muslims in Europe and the

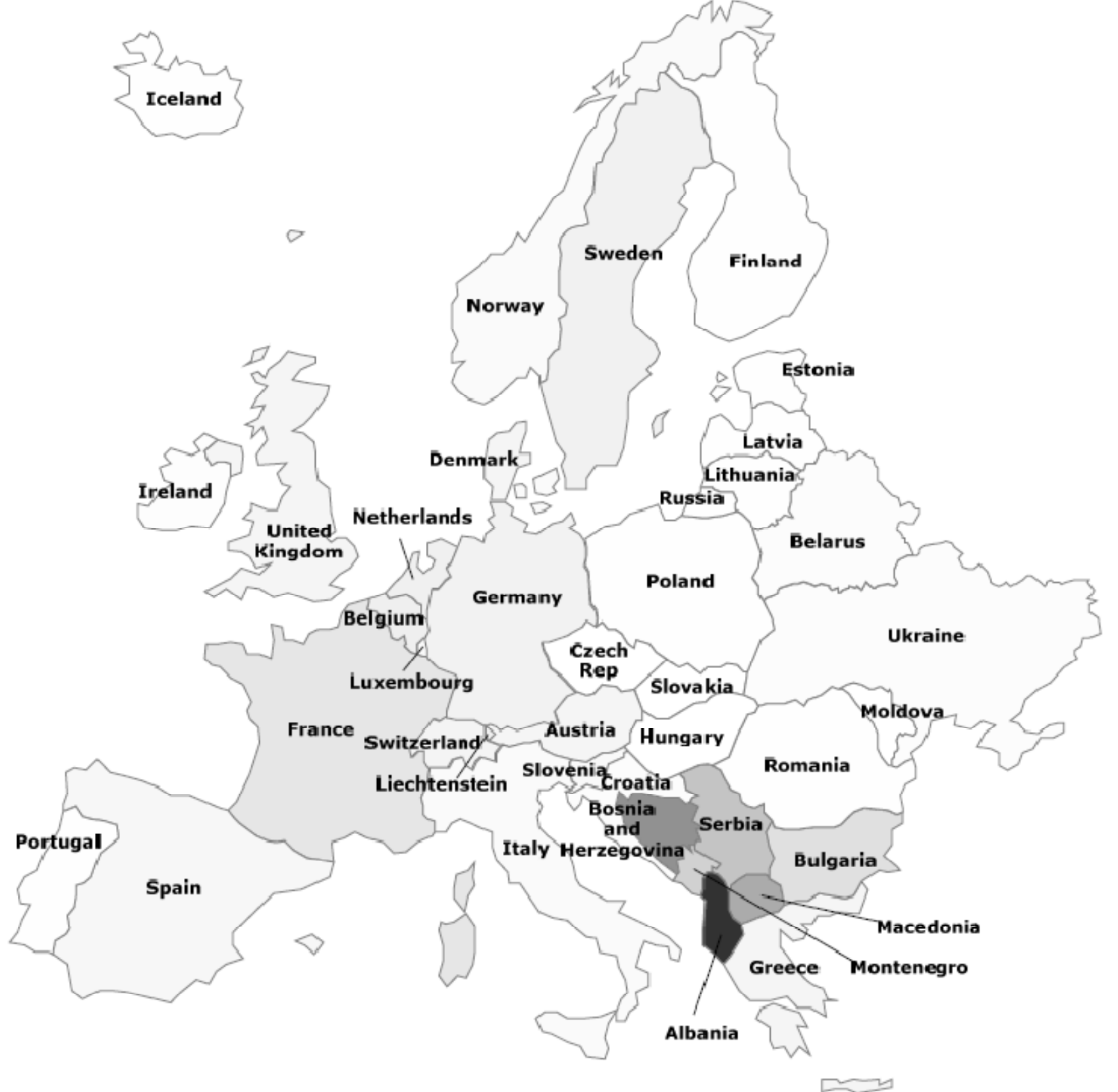

Figure 8. A color coded map of Europe illustrating the presence of Muslims in the continent as of 2010. 
Americas)", إدريسس دار (Dar Idriss), Beirut, Lebanon, 1976.

[17] [KET] A. Kettani, "Muslim Minorities in the World Today," London: Mansell Publishing, 1986.

[18] A. Kettani, "اليـوم العـالم فــي الإســـلامية الأقلي (Muslim Minorities in the World Today)," المنــارة مكتبـــــ (Maktabatul Manara), Mecca, Saudi Arabia, 1988.

[19] "Liechtensteinische Volkszählung 2000: Religion und Hauptsprache," Liechtensteinische Landesverwaltung, Vaduz, Liechtenstein, December 2005.

[20] "Recensement general de la population 2008 principaute de Monaco," Division des Statistiques des Etudes Economiques de la Direction de l'Expansion Economique, Mairie de Monaco, May 2009.

[21] "Population Census 2004," Statistical Compilation, Volume 1, National Bureau of Statistics of the Republic of Moldova, Chişinău, Republic of Moldova, 2006.

[22] "Statistical Yearbook 2009," Montenegro Statistical Office, December 2009.

[23] "Statistical Yearbook of the Republic of Macedonia," State Statistical Office, Republic of Macedonia, 2009.

[24] "Census 2001 output, Northern Ireland census 2001 univariate tables," Northern Ireland Statistics and Research Agency, November 2003.

[25] "Nearly one million Muslims in the Netherlands," Web Magazine, Statistics Netherlands, September 20, 2004.

[26] "Nearly as many Muslims as Calvinists in the Netherlands," Web Magazine, Statistics Netherlands, October 13, 2003.

[27] "Nearly 900 thousand Muslims in the Netherlands," Web Magazine, Statistics Netherlands, November 18, 2002.

[28] "Religious and life stance communities," Statistics Norway, December 2009.

[29] "Mapping the Global Muslim Population, A Report on the Size and Distribution of the World's Muslim Population," Pew Forum on Religion \& Public Life, Pew Research Center, October 2009.

[30] "Censos 2001 resultados definitivos," Instituto Nacional de Estatística, Lisboa, Portugal, October 2002.

[31] "Pridnestrovie's population," pridnestrovie.net, 2006.

[32] Á. Varga, "Hungarians in Transylvania between 1870 and 1995," Teleki László Foundation, Budapest, Romania, March 1999.

[33] "2002 All-Russia Population Census," Information and Publishing Center, Statistics of Russia, Moscow, Russia, 2005.

[34] "Census of Population, Households and Housing, Slovenia, 31. March 2002," Statistical Office of the Republic of Slovenia, April 2003.

[35] "Analysis of religion in the 2001 census - Summary Report," Office of the Chief Statistician, Scottish Executive, February 2005.

[36] РГАЭ the Russian Federation (быв. ЦГАНХ the USSR), fund 1562 , the inventory 336 , a unit xp. 1566a-1566d (Table 3.4 population distribution on a nationality and a native language)

[37] "Ukraine Demographic and Health Survey 2007," Ukrainian Center for Social Reforms, State Statistical Committee, and Ministry of Health, Kyiv, Ukraine, Macro International Inc., Calverton, Maryland, U.S.A., September 2008.

[38] R. Kerbaj, "Muslim population 'rising 10 times faster than rest of society'," the Times, London, UK, January 30, 2009.

[39] "Demographic Yearbook Special Census Topics, Volume 2b Ethnocultural characteristics, Table 6 - Population by religion, sex, urban/rural residence: each census, 1985-2004," Statistics Division, Department of Economic and Social Affairs, United Nations, New York, June 2006.

[40] "Population and Vital Statistics Report, Statistical Papers, Series A Vol. LXI, No. 1," Statistics Division, Department of Economic and Social Affairs, United Nations, New York, September 2009.

[41] "World Population Prospects, the 2008 Revision," Population Division, Population Estimates and Projections Section, Department of Economic and Social Affairs, United Nations, New York, May 2009.

[42] "Demographic Yearbook 1988, Table 29 - Population by religion and sex: each census, 1979-1988," Statistical Office, Department of International Economic and Social Affairs, United Nations, New York, 1990.

[43] "Demographic Yearbook 1983, Table 29 - Population by religion and sex: each census, 1974-1983," Statistical Office, Department of International Economic and Social Affairs, United Nations, New York, 1985.

[44] "Demographic Yearbook 1979, Table 29 - Population by religion, sex and urban/rural residence: each census, 1970-1979," Statistical Office, Department of International Economic and Social Affairs, United Nations, New York, 1980.

[45] "Demographic Yearbook 1973, Table 31 - Population by religion, sex and urban/rural residence: each census, 1965-1973," Statistical Office, Department of Economic and Social Affairs, United Nations, New York, 1974.
[46] "Demographic Yearbook 1964, Table 32 - Population by religion and sex: each census, 1955-1964," Statistical Office of the United Nations, Department of Economic and Social Affairs, United Nations, New York, 1965.

[47] "Demographic Yearbook 1956, Table 8 - Population by religion and sex: each census, 1945-1955," Statistical Office of the United Nations, Department of Economic and Social Affairs, United Nations, New York, 1957.

[48] "The Serbian Questions in The Balkans," Faculty of Geography, University of Belgrade, Belgrade, Serbia, 1995. 